\title{
FEMINIST INTERSECTIONALITY RESEARCH IN COMMUNICATIONS: ORIGINS, CONTRIBUTIONS AND TENSIONS
}

\begin{abstract}
The text considers some of the important work in intersectionality that has been done by critical feminist and postcolonial scholars in media and other communication fields since the 1990s, focusing particularly on the kinds of problems they have examined and their contributions to feminist theory building. The discussion also explores some of the challenges and tensions that accompany scholarship conducted from a standpoint of intersectionality.
\end{abstract}

Keywords: Intersectionality, Critical feminist media studies

\section{Resumo Tensões \\ Investigação Feminista Intersecional em Comunicação: Origens, Contributos e \\ O texto considera alguns dos trabalhos importantes sobre intersecionalidade que foram elaborados por investigadores/as feministas críticos/as e pós-coloniais na área dos media ou em outros campos da comunicação desde a década de 1990, focalizando particu- larmente nos tipos de problemas que levantaram e nas suas contribuições para a construção da teoria feminista. A discussão também explora alguns dos desafios e tensões que acompa- nham a investigação conduzida do ponto de vista da intersecionalidade.}

Palavras-chave: Intersecionalidade, Estudos feministas críticos dos media

\section{Resumen}

Investigación Feminista Intersecional en Comunicación: Orígenes, Contribuciones y Tensiones

El texto considera algunos de los importantes trabajos sobre intersecionalidad elaborados por investigadores/as feministas críticos/as y post-coloniales en el área de los media o en otros campos de la comunicación desde la década de 1990, centrándose especialmente en los tipos de problemas que plantearon y en sus contribuciones para la construcción de la teoría feminista. La discusión también explora algunos de los retos y tensiones que acompañan la investigación conducida desde el punto de vista de la intersecionalidade.

Palabras clave: Intersecionalidad; Estudios feministas críticos de los media

Department of Communication, Culture \& Media Studies, Howard University 525 Bryant St., NW, Washington, DC, 20059, USA.

E-mail: cbyerly@earthlink.net

https://www.howardmediagroup.org/researcher/carolyn-byerly-phd 


\section{Introduction}

Scholars come to their work based on how they view the world (ontology), how they believe knowledge should be generated (epistemology), and what they believe the researcher's relationship should be to the thing studied (axiology) (Miller 2005). Of any research tradition, critical scholars are the most likely to break with the notions of maintaining distance to achieve «objective» inquiry. Instead, critical scholars tend to share the values and even experiences of the human communities they are concerned with in their work, and to reveal their scholarly relationship to the research they have undertaken. In addition, critical scholars engage in research and theory-building as change agents. As a feminist critical scholar, the following commentary on intersectionality situates my own longtime history as a feminist political activist within my scholarly attitudes and understandings of intersectionality research.

Intersectionality has come to define both a way of understanding the complexity of power relations (theory) as well as an approach to examining it (methodology). Wallis (2015) reminds us that the phenomenon of intersectionality, i.e. the complex intersection of identities that produces discrimination and marginalization, was recognized by critical scholars some time before Crenshaw (1993) used the term to set forth a specific theory of oppression. Crenshaw, a professor of law and a critical race scholar, posed her theory of intersectionality in the late 1970s to assert that individuals are discriminated against in several ways simultaneously. Her work was a breakthrough in legal studies because it offered a structural framework within which to understand the institutional basis of discrimination along more than one axis of oppression. As it would turn out, her important contribution to legal studies quickly caught on, offering the foundation for critical feminist and race scholars in other disciplines to develop their own lines of inquiry that integrated concerns about gender, sexuality, race, social class and nationality.

My goal here is to consider some of the important work that has been done by critical feminist and postcolonial scholars in media and other communication fields since that time, focusing particularly on the kinds of problems they have examined and their contributions to feminist theory building. In addition, I will explore some of the challenges and tensions that accompany doing scholarship from a standpoint of intersectionality.

To state my own position at the outset, I am a proponent of intersectionality scholarship, which defines my research and also my teaching. I believe one comes to intersectionality through consciousness born of lived experience as much as academic training. In addition, I recognize the difficulty of applying intersectionality in empirical work, which demands not just an overarching theory but one that enables analyses that rest on evidence. This is among the tensions to be explored. 


\section{Coming to intersectionality}

My own path to intersectionality was through the feminist anti-violence movement of the 1970s and 1980s when our rape crisis centers and women's shelters were seeing clients whose victimization was always complex and whose encounters with hospitals, police, courts and even therapists were too often textbook cases of institutional discrimination. Of course, our clients' lives also mirrored and paralleled what those of us doing this frontline activism had (and were) experiencing in our own lives. The anti-violence movement against sexual abuse and domestic violence represented the vanguard of second wave feminism, turning largely invisible personal traumas into public problems for political action. Within our organizations we spent countless hours sharing, reflecting, analyzing, and strategizing for change while we also supported our clients and each other. I had multiple roles in the movement, first as a volunteer who helped local centers develop public education and media campaigns (drawing on my journalism and public relations training), then as a volunteer client advocate, and finally as the director of a center.

The lessons from those years are endless, but in the context of intersectionality, one exemplar comes clearly to mind in the time when one of our rape advocates accompanied a Latina woman to the police after she had been beaten and raped by a boyfriend. The woman was dark skinned, spoke fairly good English but with an accent, and her clothing and physical appearance suggested she was poor. The police officer who took her statement that night directed his attention and questions mainly to the white, middle-class, educated advocate accompanying her throughout the statement-taking, referring to the woman as «she» and «her» without addressing the woman herself. Within the institutional setting of that police station, the woman was made invisible, her personhood was demeaned, and her victimization was both trivialized and anonymized. Those of us in the movement that challenged men's dominance of, and violence toward, women recognized that these situations could only be fully understood and addressed by bringing all of the factors together. We also had to factor in racism, classism, ethnocentrism, national origin and homophobia that we saw in the institutional practices that surrounded and enabled the violence to exist. In the process, we also had to call out the demons in our own lives, in our family and personal relationships, and in the communities that had shaped us. The intersectionality consciousness was thus born.

I entered my academic life a few years later where yet another world was opened to me. My academic starting point would be the insights shaped by those years working in the feminist anti-violence movement, which taught me to question the world from an intersectional standpoint. Other critical scholars will have their own paths and stories to tell, but there is a predictable certainty that if they do intersectional scholarship, they too will have come to it through a consciousness-raising process of lived experience that compelled them to embrace the com- 
plexity of power relations in society, as well as a dedication to using their scholarship for social change. I do not think I know a single scholar who does this kind of research who does not also engage politically in the issues and problems that they investigate and theorize.

\section{The work of intersectional feminist scholars}

In her effort to survey the work of feminist communication theory, Cucklanz asserts that

At its best, feminist theory in communication should account for not only the interplay of gender and power but also the relevance of other textual elements including race, sexuality and class. Power imbalances of gender are understood as intersecting with power relations of class, race, sexuality and other categories including religion and ethnicity. Sophisticated feminist communication theory should attempt to take these various elements into account. (Cucklanz 2016, 1)

Cucklanz articulates an emerging consensus among critical feminist communication scholars today. Consider similar pronouncements by others.

Introducing her book African American Women in the News: Gender, Race and Class in Journalism, Meyers notes that

The overarching research questions are: (1) how are African American women portrayed in the news; and (2) how does this coverage reflect intersectionality - that is, the complex and varied ways that gender, race, class and other markers of social identity are inextricably linked within a hierarchy of dominance. [...].

[...] As the chapters in this book make clear, intersectionality is central to representation - and conclusions based on studies that ignore the complexities of intersecting aspects of identity are, inevitably, limited and limiting. (Meyers 2013, 2)

In her eponymous book on humanities scholar bell hooks' contributions to communication studies, Squires observes that hooks conceptualizes dominator culture as «a matrix within which different groups are arrayed in overlapping, interlocking hierarchies of privilege and oppression» in which all members of these groups have been shaped by «ideological frameworks of domination» (Squires 2013, 19). Like other Black feminist theorists, hooks has analyzed media with attention to the multiple identities that shape power relationships, says Squires, who adds that Black feminists employ intersectionality in such investigations by

centering Black women's experiences, theorizing from the specific ways in which gender, class, sexuality, and age all contribute to how domination structures the lives and life chances of Black women. Importantly, intersectional analysis from Black feminists 
emphasizes that the matrix of power and identity is not all-encompassing; rather, Black women and other oppressed people have theorized resistance and alternative habits of mind from their specific standpoint. (Squires 2013, 19)

The application of intersectionality in feminist communication research is perhaps seen in its most expansive possibilities through the work of feminist postcolonial scholars. In her examination of the media coverage of Nafissatou Diallo's sexual assault charges against Dominique Strauss-Kahn in 2011, when Diallo was a maid at a New York hotel and Strauss-Kahn was chief of the International Monetary Fund, Hegde (2012) illustrates the essentiality of intersectionality analysis. Recognizing that Diallo was a woman, a migrant (from West Africa), Black, Muslim, and poor, she observed:

The gendered subject came into visibility framed as a mediatized spectacle or scandal and was soon folded into the logics of nationalism, patriarchy, whiteness and citizenship. These mediatized events involving immigrants reinforce hegemonic views of citizenship by redrawing the border between the insider and outsider. The binaries and rigid cultural polarities emphasize the distance between the dominant society and those on the margins. (Hegde 2012, 20)

Hegde, a feminist postcolonial scholar, notes that such coverage serves as a reminder to critical scholars to pay attention «to the intersecting logics of race, class and gender that underwrite normative conceptions of the public and public sphere,» because the idea of the public sphere, which conceptualizes the space of deliberation and participatory communication, «has traditionally been inscribed within the frame of the national» $(2012,20)$. The point here is that understanding such stories requires an intersectionality approach that considers gender, race and class, as well as religion, nationality, and the politics of migration, the last of these situated within a global framework. She problematizes the concept of globalization, which she says is «riddled with glaring contradictions» $(2012,24)$, among them the failure of scholars of globalization to pay adequate attention to race, class, sexuality and national boundaries.

Shome (2011), another feminist postcolonial scholar, similarly demonstrates that intersectionality theory has become a staple of feminist communication scholarship in her examination of the ways that White femininity becomes a transnational phenomenon in western media that portray prominent White women as the saviors and rescuers of children from underprivileged parts of the world. Shome calls this a discourse of global motherhood, in which White women like Mia Farrow, Madonna, and Angelina Jolie, among others, reconstitute their families as multicultural global families through adoption. Applying intersectionality analysis that recognizes gender, race (particularly Whiteness), nation, and political economy (as manifested in neoliberalism), and incorporating Gilroy's concept of transnational intimacies, she says: 
The concept of transnational intimacies additionally highlights the intimate transnational struggles of maternities and modernities through which White western women (especially in nations such as the U.S./U.K.) come to function as global mothers. Maternities and modernities are intimately linked. The modern is gendered. Ideas about good mothers - competent mothers - are centrally tied to the imagination of a healthy and civilized nation [...]. Consequently when we see White women caring for children of other nations, or absorbing these children into the affective vectors of their own kinship relations, we need to recognize that underlying such discourses is a struggle over maternities and modernities. (Shome 2011, 390-391)

\section{Tensions within Intersectionality}

How is intersectional analysis undertaken to assure that it truly engages all of the various vectors of power? And, in doing intersectional analysis, is it really possible to consider the various elements of power equally? In other words, with any given problem or situation under scrutiny, do one or two elements surface as the most salient, requiring the others be considered as secondary aspects? Meyers' study of news about Black women clearly and overtly focuses on gender, race and class, and not the wider spectrum of possible markers of power, such as sexuality or religion or national origin. For all of its interdisciplinary impact, doesn't hooks' work really place race and gender at the top of her intersectional concerns?

The matter of the hierarchy of concerns in intersectionality has been raised most clearly by Marxist feminists like Eve Mitchell (2013), who argues that critical feminist scholars who pursue this type of research seem to forget about how gender relations developed under capitalism, something that has been a key determinant of power in men's and women's relationships, both in the home and the workplace. Capitalism has similarly shaped race relations, she asserts, and looking to D'Emilio's work, she offers a parallel explanation for sexual hierarchy in which heterosexual behavior and identity have dominated in labor relations that arose under capitalism. Moreover, she moves the roots of intersectionality to class struggles of the 1960s and 1970s in the United States and Europe over gendered and racialized divisions of labor. To illustrate feminist theoretical blind spots, she notes that within second wave feminism, the demands for «equal pay for equal work» (and, we might add, demands for an end to gender-segregated job ads) emphasize the centrality of labor to the women's movement, but these were demands that lacked a materialist analysis. Simply adding women into the existing labor market as it was structured, i.e., giving them equality with men, also served to reproduce capitalist class relations, she says. Characterizing intersectionality as concerned with «identity politics,» and therefore bourgeois, Mitchell argues that:

To be a «woman» under capitalism means something very specific; it is even more specific for women in the US in 2013; it is even more specific for individual women. 
But in a universal sense, to be a «woman» means to produce and reproduce a set of social relations through our labor, or self-activity. Taking a cue from [Franz] Fanon, our method must argue: I am a woman and a human. We must recognize the particular in conversation with the totality; we must consider a moment or a single expression of labor in relationship to labor itself. (Mitchell 2013, n.p.)

Her recommendation is to consider gender or sexuality or race relations within class, something echoed by other Marxists who recognize the challenge of navigating multiple oppressions and believe that this can be accomplished by going to the element that provides the structural framework for the multiple oppressions.

Wallis is particularly articulate on this point, recognizing that, «in a world rife with oppression, intersectionality is a revolutionary value» but only «insofar as it implicitly condemns relations of domination» $(2015,605)$. He challenges us to ask:

In what precise ways do the oppressions intersect? Does one dimension of oppression simply add onto another, configuring a cumulative heap of oppressions that must then be dismantled one by one, each through the actions of its own constituency? Or is there a structure that links the oppressions together in some historically discernible way? And, if there is such a structure, what is the nature of the links and how did they come to acquire their present form? (Wallis 2015, 605)

The task of the scholar, according to Wallis, is to identify the conditions or practices that cut across all of the oppressions, thereby uniting them to form an intersection: «We are thus centrally concerned with intersectionality, but on the premise that in order to properly address it, we must target the structural underpinning of the practices that have to be ended» (Wallis 2015, 605). Numerous Marxist feminist theorists - Sheila Rowbotham (1972), in Women, Resistance and Revolution; Angela Davis (1981), in Women, Race and Class; Johanna Brenner (2000), in Women and the Politics of Class, among others - have similarly argued this point. And though the applications of intersectionality as well as the debates surrounding it have been increasingly refined, Wallis believes that «the original goal of intersectionality theory - that of binding the oppressed constituencies together into a coherent political force - has not been realized» $(2015,607)$. In other words, he says, «there is as yet no entity capable of challenging the grip on power of those who, as a class, shape every aspect of society» $(2015,607)$. Wallis considers that:

White supremacy, male supremacy, and heteronormativity are components of a larger system of power, within which each plays a strategic role, buttressed by institutions that are kept going because, in complex and sometimes contradictory ways, they reinforce the overall constellation of class power. (Wallis 2015, 211) 


\section{Conclusion: Remembering dialectics}

This argument resonates with me in the later stages of my own work, which has reached increasingly to Marxist analysis of capitalist relations to examine the problems of gender and race in the media. ${ }^{1}$ For the last decade, I have been examining communication policy with respect to its enablement of media conglomeration and the further marginalization women and racial minority ownership in the United States. In addition, I have looked to the effects of under-representation of women and minorities on media companies' boards of directors. Media (and other corporate) conglomeration is a phenomenon in nearly all nations today, and it specifically marginalizes women and the poor (Byerly 2013). In all cases, these macro-level inquiries have taken me face-to-face with the structure of capitalism in which those in the powerful elite class have been able to dominate by financing their candidates for public office and in doing so also affect communication policy to serve their interests. With some few exceptions, since the 1970s the members of the US Congress, as well as every president, have followed a philosophy of pro-corporate neoliberal policy that privileges the wealthy male elite and, in this particular nation, also those who are White.

But the lessons of Marxism are many for those of us with an activist history. My deeply feminist sensibilities that have required me to understand women's oppression alongside other forms of oppression also require me to seek the center of power if I am to engage in responsible scholarship or political change work. Why is it that those of us on the margins of such power have such difficulty doing this, I wonder, even those of us in the academy who possess the analytical tools and intellectual positionality. The elites who possess the dominant power have none of this reticence. There is no better example than our present situation in the US, where, since 2016, we have witnessed the advance of multi-billionaire Donald Trump to the presidency, boasting loudly from the beginning of his candidacy that he is very, very rich. Once elected, he appointed nearly all very, very rich White men similar to himself to head the various federal agencies. The task of these agency heads is ostensibly to dismantle the institutions they now oversee, or at least to greatly interfere with their missions of protecting the environment, assuring fair labor relations, fostering a vibrant public school system and other purposes for which they were established. Are we, as Wallis $(2015,613)$ argues,

See for example Byerly, Carolyn. M., Park, Yong Jin \& Reginald Miles. 2011. «Race and genderconscious policies: Toward a more egalitarian communications future». Journal of Information Policy, 1: 425-440; Byerly, Carolyn M. \& Alisa Valentin. 2016. «Women's access to media: Legal dimensions of ownership and employment in the United States». In Race and gender in electronic media: Challenges and opportunities, ed by Rebecca Lind. New York: Routledge; Byerly, Carolyn M. 2014. «Media Conglomeration and Women's Interests: A Global Concern (commentary)», Feminist Media Studies, 14(2): 322-326. 
living in «an ideological climate purged of the idea of class conflict» to such an extent that we cannot see, comment and act?

There is no obvious way forward in capitalist nations that are experiencing a resurgence of authoritarianism today than to confront class relations as a starting point to re-visioning broader liberation struggles. Intersectionality scholars cannot investigate or address the under-representation of women or people of color in media without considering who owns the media, and this takes us headlong down a linear path of media ownership, communications policy, and the structures of capitalism that allow discriminatory practices. The next stage of development in intersectionality scholarship for feminist and other critical scholars is to reframe our questions to focus on the multiple forms of oppression associated with the specific practices that harm us, but to do so recognizing the agency exercised by capital inherent in the phenomena we scrutinize.

\section{References}

Byerly, Carolyn M. 2013. «Factors affecting the status of women journalists: A structural analysis». Pp. 11-26 in The Palgrave international handbook of women and journalism, edited by Carolyn M. Byerly. Basingstoke, UK: Palgrave Macmillan. Doi: https://doi. org/10.1057/9781137273246_2

Crenshaw, Kimberle. 1993. «Mapping the margins: Intersectionality, identity politics, and violence against women of color». Stanford Law Review 43 (6): 1241-1299. Doi: https:// doi.org/10.2307/1229039

Cucklanz, Lisa. 2016. «Feminist theory in communication». Pp. 1-11 in The international Encyclopedia of communication theory and philosophy. John Wiley \& Sons. Doi: https:// doi.org/10.1002/9781118766804.wbiect157

Hegde, Radha. S. 2012. «Gender, globalization and the politics of visibility». Pp. 19-26 in Medien, Öffentlichkeit und Geschlecht in Bewegung, edited by Tanja Maier, Martina Thiele and Christine Linke. Belefeld, Germany: Transcript.

Meyers, Marian. 2013. African American women in the news: Gender, race, and class in journalism. New York: Routledge.

Miller, Katherine. 2005. Communication theories: Perspectives, processes and contexts. 2nd ed. New York: McGraw Hill.

Mitchell, Eve. 2013. «A Marxist-feminist critique of intersectionality theory». https://libcom. org/library/i-am-woman-human-marxist-feminist-critique-intersectionality-theory-eve-mitchell

Shome, Raka. 2011. ««Global motherhood»: The transnational intimacies of White femininity». Critical Studies in Media Communication 28 (5): 388-406. Doi: https://doi.org/10.1 080/15295036.2011.589861

Squires, Catherine R. 2013. bell hooks: A critical introduction to media and communication theory. New York: Peter Lang.

Wallis, Victor. 2015. «Intersectionality's binding agent». New Political Science 37 (4): 604-619. Doi: https://doi.org/10.1080/07393148.2015.1089032 
Carolyn M. Byerly. Professor and chair of the Department of Communication, Culture and Media Studies at Howard University, Washington, DC. She takes a critical political economy approach in her research on gender and race issues in media, including employment and ownership. She is the co-author of Women and Media: A Critical Introduction, and editor of the Palgrave International Handbook on Women and Journalism, as well as other books and more than 50 articles and book chapters.

Article received on 04 April 2017 and accepted for publication on 31 May, 2017. 